\title{
Post w Starym Testamencie
}

Prawie we wszystkich religiach spotykamy się z pojęciem postu. - Wynika ono z wewnętrznej potrzeby duszy ludzkiej nieustannie tęskniącej za Bogiem. Potwierdzenie tej tezy znajdujemy na wielu miejscach Starego Testamentu. Post u Izraelitów nie zaczyna się od Mojżesza. Jest on tak starym, jak stara jest historia całego narodu wybranego.

POJECIE POSTU. Stary Testament na określenie postu posługuje się dwoma słowami: cum $i$ ta 'anit ${ }^{1}$ ). Słowo şum jest najogólniejszym wyrażeniem w tej kwestii. Spotykamy się z nim w języku aramejskim, arabskim i etiopskim. Izajasz używa go na równi ze słowem ta 'anit, od 'anah zająć niskie miejsce, w nifal upokorzyć się, w hitpael ugiąć się przed Bogiem. $Z$ biegiem czasu Izraelici obú tym wyrażeniom nadadzą jedno i to samo znaczenie i używać ich będą paralelnie. Dowodem tego powiedzenie psalmu 35, 13: 'inneti baçom naphszi =, dręczyłem w poście duszę moją“" Z biegiem czasu opuszczono słowo çum i mówiono krótko 'inna naphszo, od czego urobił się rzeczownik ta 'anit dręczenie, umartwienie, którego dziś używamy na określenie postu. Stąd istota postu polega na zajęciu odpowiedniego stanowiska wobec Boga. Stanowisko to jest zupełnie jasne: pokorne podejście do Boga przy równoczesnym úmartwieniu duszy. Autor ks. Kapł. nazywa je dosadnie: dręczeniem duszy ${ }^{2}$ ). Naród izraelski wydaje się rozumiał to pojęcie. Żali się bowiem pŕzez usta proroka Izajasza do Boga: Czemuśmy pościli, a nie wejrzałeś, poniżyliśmy dusze nasze a nie widziałeś ${ }^{3}$ ). Pan Bóg nie przyjął tego postu, bo był on niezupełny. Brakowało w nim ureğulowania stosunku do bliźnich. Oto w dzień postu waszego - mówi Izajasz $(58,3)$ - ...wszystkich robotników swoich ciśniecie, oto na swary i na zwady pościcie, izali to názwiesz postem i dniem przyjemnym Panu. Pan Bóg inaczej sobie post wyobraża. To jest raczej post, którym obrat: rozwiąz więzy niezbożności, rozwiąz brzemiona ciązace, wypuść niewola ucisnionych, ułam łaknacemu chleba, a ubogich i tułajacych się wprowadź do domu swego, gdy ujrzysz nagiego przyodziej go ${ }^{4}$ ). Oprócz tych momentów w pojęcie postu wchodzi jeszcze jako zasadnicza jego cecha: motyw religijno-moralny. Izraelici pościli w czasie niewoli babilońskiej

1) Por. W. Gesenius, Hebr. u. Aram. Handwörterbuch über das Alte Test. Leipzig, 1921, str. 603 n, 677 n.

$\left.{ }^{2}\right)$ Por. ks. Kapł. 16, 29.

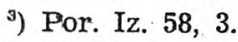

4) Por. Iz. $58,4 \mathrm{nn}$. 
w rocznicę zdobycia i zburzenia Jerozolimy i świątyni, jak również w rocznicę zamordowania Godaljasza. Post ten w oczach Boga nie miał żadnego znaczenia. Był on raczej zewnętrznym objawem żałoby narodowej, dowodem wielkiego patriotyzmu, ale pozbawiony pobudek religijnych i dlatego nie przyjęty przez Boga. Gdyście pościli i plakali mówi P. Bóg - piątego i siódmego przez te 70 lat, izaliście mnie post pościli $\left.{ }^{5}\right)$. Nie robiono to $\mathrm{z}$ czysto zewnetrznych pobudek. Wielu nawet Izraehitów traktowało post czysto powierzchownie. Byli głęboko przeko= nani ${ }^{6}$ ), że można wieść grzeszne życie, byle by tylko wstrzymać się w przepisanym przez prawo dniu od pokarmów i napojów. Wtedy porachunki z Bogiem są wyrównane. Zdumienie ich ogarnęło, gdy się dowiedzieli z ust Jeremiasza, że takiego postu i takiej modlitwy Bóg nie przyjmie $\left.{ }^{7}\right)$. - Post ma w sobie jeszcze coś z żalu i smutku. Dlatego nie poszczono nigdy w sobaty i święta, które zwykle miały charakter radosny. Nie poszczono także podczas uroczystości weselnych. Szczególnie przyjaciele narzeczonego byli wolni od postu i innych éwiczen religijnych. Do tych wszyștkich zasadniczych moltywów postu dopiero na samym końcu należy dołączyć zakaz spożywania pewnych pokarmów i napojów. Zakaz ten nie wchodzi jako integralna część postu, ale jako jego dopełniènie, ułatwiające zrozumienie $i$ wniknięcie całkowite $w$ istote postu. Zakaz ten obejmował dłuższy lub krótszy okres czasu, zaleźnie od tego, na ille dni post był przewidziany. Post jako taki nie ma nic wspólnego z zakazem używania pewnych potraw i pokarmów. Zakaz ten ma raczej zabarwienie narodowo-religijne, które trzeba odróżnić od religijno-moralnego charakteru postu. W ten sposób rozważone pojęcie postu byłoby trapieniem duszy ze względu na Boga i bliźnich, opartym na mocnym fundamencie religijno-moralnym.

CEL i MOTYWY POSTU. Jak wynika z Pisma św., Izraelici pościli zwykle w ciężkich i przełomowych chwilach swojego życia, osobistego i narodowego. Stąd pierwszym celem postu było przebłaganie sprawiedliwego Boga.

Było ono połączone z poczuciem własnej grzeszności. Gdy narodowi groziła klęska z powodu plagi szarańczy, zjawia się prorok Joel, który jedyny ratunek dla Izraela widzi w poście: Przepaszcie się, a płaczcie kaplani... poświęćcie post, zwołajcie gromade, zbierzcie starców i wszyst-

$\left.{ }^{5}\right)$ Por. Zach. 7, 5 .

$\left.{ }^{6}\right)$ Por. P. Heinisch, Theologie des A. T., Bonn, 1940, s. 216.

7) Por. Jer. 14, 12. 
kich mieszkańców ziemi... bo blisko jest dzień Pański ${ }^{8}$ ). Naogół lud pod tym względem przyznawał słuszność prorokom i słuchał ich głosu. Skutek takiego postu był zawsze pozytywny. Prorok Jonasz na podstawie faktu $\mathrm{z}$ własnego życia, mówi: I uwierzyli mężowie Niniwici w Boga $i$ zapowiedzieli post $i$ oblekli się $w$ wory od największego do najmniejszego... i zlitował się Bóg nad złem, które był rzekł, że im uczyni i nie uczynit ${ }^{9}$ ). Izraelici, któnzy gorliwsze wiedli życie, nie zwlekali z postem aż do chwili, gdy ręka Pańska ich dotknie, pościli często w celu uproszenia sobie Bożego miłosierdzia.

Charakterystyczną cechą tego postu był szczery żal i poczucie własnej grzeszności, wynikające $z$ tego przekonania, że ozłowiek nigdy nie jest doskonałym. Dlatego Dawid kładzie na siebie włosiennicę i trapi postem duszę swoją ${ }^{10}$ ), chociaż nie poczuwa się w danej chwili do żadnej winy. Podobnie czyni Anna, żona Elkana Lewity ${ }^{11}$ ). Do tego nodzaju postów należy zaliczyć post Estery ${ }^{12}$ ) nadzwyczaj religijnej i bohaterskiej niewiasty żydowskiej. Estera zdaje sobie sprawę $z$ tego, że naród cały .zgrzeszył, ale liczy na miłosierdzie Boże i postem pragnie przebłagać sprawiedliwego Sędziego.

Pościli też Izraelici z różnych względów natury społecznej i prywatnej. Post o charakterze społeczuym obowiązywał wszystkich. StrackBillerbeck ${ }^{13}$ ) podaje, że miał on miejsce podczas nieurodzaju, posuchy, plagi szarańczy, napadu dzikich zwierząt, lub gdy groziły krajowi ciężkie i niebezpieczne wojny. Często gdy naród zbierał się na narady i miał decydować o ważnych sprawach, uciekał się do postu, jako jednego z niezawodnego pomocniczego środka. Tak było w czasie wojny Izraela z Benjaminitami ${ }^{14}$ ), przed walką Judy $z$ Moabitami i Amonitami ${ }^{15}$ ), w czasie oblężenia Betulii przez wojska Holofernesa ${ }^{16}$ ), lub też przed pokonaniem Gorgiasza i Nikanora ${ }^{17}$ ).

Do rzadkości należał post z połudek li tylko osobistych. Czytamy o nim w St. Testamencie, zwłaszcza z powodu śmierci drogich osób. Tak

8) Por. Joel 1, 13.

9) Por. Jon. $3,5,10$.

$\left.{ }^{10}\right)$ Por. Ps. 34 (35), 13; także II Król. 3, 35.

11) Por. I Król. 1, 7.

12) Por. Est. 4, 16.

$\left.{ }^{13}\right)$ Por. Strack-Billerbeck, Exkurse zu einzelnem Stellen des N.-Test., München 1928, t. IV, s. 82.

1i) Por. ks. Sędz. 20, 26.

15) Por. II Kron. 20, $3 \mathrm{nn}$.

$\left.{ }^{16}\right)$ Por. Jutd. 6, 20; także Ezdr. 8, 21.

17) Por. I Mach. 3, 46. 
mieszkańcy Jabeš Galaad opłakują śmierć Saula i synów jego i poszczą później siedm dni ${ }^{18}$ ). Dawid zaś pości po śmierci Abnera ${ }^{19}$ ). Praktykowano też post jako środek upraszający łaski Boże, a nade wszystko wzmacniający wartość modlitwy. Z tej strony podchodzi do postu prorok Daniel, kiedy mówi: $i$ obróciłem oblicze moje do Pana Boga mego, abym prosit $i$ modlit się $w$ postach $w$ worze i w popiele ${ }^{20}$ ). Potwierdza te jego slowa autor ks. Tobjasza: Dobra jest modlitwa $z$ postem ${ }^{21}$ ). W czasach talmudycznych post miał taką samą wartość, jak modlitwy i ofiary. ${ }^{22}$ ). Naogół poza małymi wyjątkami, motywy i pobudki postu były czysto zewnętrzne o mocnym egoistycznym zabarwieniu. Zwróci na to uwage kilka wieków później sam Pan Jezus, gdy będzie oceniał wartość postu u faryzeuszów: a gdy pościcie, nie bądźcie jak obłudnicy smutni; albowiem twarze swoje wyniszczaja, aby się ludziom wydali poszczacymi... Ale ty gdy pościsz, namaśc̉ głowe twoja i umyj oblicze swoje, abyś sie nie okazat ludziom, że pościsz, ale Ojcu twemu, który jest w skrytości; a Ojciec twój, który widzi w skrytości, odda tobie $\left.{ }^{23}\right)$.

RODZAJE POSTU. Ze względu na czas powstania, możemy podzielić posty Izraelitów na istniejące: a) przed niewolą, b) od czasu niewoli babilońskiej.

ad a) Zasadniczo przed niewolą istniał tylko jeden ścisły i bardzo ważny post. Był to post na wielki dzień pojednania. Poza Pięcioksiągiem nie mamy nigdzie o nim wzmianki w Starym Testamencie. Obchodzono go 10 Tiszri (koniec września, początek października), stosownie do rozkazu danego przez Boga Mojżeszowi: Dziesiątego dnia miesiaca tego siódmego dzień oczyszczenia będzie... i będziecie weń dręczyć dusze wasze i ofiarujecie całopalenie Panu ${ }^{24}$ ). Dzień ten nosił w hebrajskim języku nazwę coma raba = wielki post. Był istotnie postem bardzo wielkim. Miszna ${ }^{25}$ ) tak się o nim wyraża: ,W dniu pojednania zabronionem jest jedzenie, pieie, namaszczanie, ubieranie sandałów i pożycie małżeńskie. Król i nowożeńcy mogą się myé, a wartowniczka nosić sandały. Gdyby ktoś zapomniał, że jest dzień pojednania i napił się i posilił, winien jest złożyć ofiare za grzechy". Do postu tego byli obowiązani

\footnotetext{
$\left.{ }^{18}\right)$ Por. I Król. 31, 13; I Kron. 10, 12; II Król. 1, 12.

$\left.{ }^{19}\right)$ Por. II Król. 3, 35.

$\left.{ }^{20}\right)$ Por. Dn. 9, 3.

${ }^{21}$ ) Por. Tob. $12,8$.

$\left.{ }^{22}\right)$ Por. Jüdisches Lexikon, Berlin, 1928, t. II. s. 591.

$\left.{ }^{23}\right)$ Por. Mat. 6, 16-6, 18.

(2) Por. ks. Kapl. 16, 29; 23, 27; Liczb. 29, 7.

$\left.{ }^{25}\right)$ Por. Miszna Joma, 8, 1; 8, 3; cyt. u Strack-Billerbeck, d. c. s. 77.
} 
wszyscy zarówno mężczyźni jak ì kobiety. Oczywiście dzieci były wolne od postu. Odnośnie do nich rozporządzenie było następujące: ,Dzieciom pozwala się w dniu pojednania na niezachowywanie postu. Jednak powinno się je przyzwyozajać do tego rok albo dwa lata wćześniej (zanim będą zobowiązani przepisem prawa, ok. $13^{-}$roku $\dot{z} y$ cia $^{26}$ ), aby były nauczone zachowywać przykazania Boże“ ${ }^{27}$ ). Post na dzień pojednania zaczynał się od zachodu słońca dnia poprzedniego, a kończył się wieczorem dnia następnego. Ponieważ obchodzono go pięć dni przed świętami namiotów, był on bezpośrednim przygotowaniem na te święta. Przykazanie Boże, dane Mojżeszowi, odnośnie do tego postu, miało obowiązyiwać na wieczne ozasy ${ }^{28}$ ).

ad b) Czasy niewoli babilońskiej dostarczyły Izraelitom smutnych okazji do ustanowienia nowych postów. Były ione następujące: poszozono 10 Tebet (styczeń) W rocznicę oblężenia Jerozolimy przez Nabuchodonozora, 9 Tammuz (lipiec) w rocznicę zdobycia świętego miasta, 9 A b (sierpień) w dniu zburzenia miasta i świątyni, oraz 3 Tiszri (październik) wo rocznicę zamordowania Godaljasźa. Do postów po niewoli zaliczyé należy także post Estery, zachowywany przed świętem Purim, ustanowiony na pamiątkę ocalenia Żydów z niewoli perskiej przez Estere i Mardocheusza ${ }^{29}$ ).

Ciztery wyżej wspomniane posty po edykcie Cyrusa i odzyskaniu wolności przez Izraelitów straciły właściwie swoją rację bytu, dlatego u niektórych wyznawców Zakonu zrodziła się wątpliwość odnośnie do dalszej ich akitualności.

E. Kalt ${ }^{30}$ ) podaje równie $\check{Z}^{\circ}$ w wątpliwość datę powstania postu Estery w czasach biblijnych, przypisując mu późniejsze pochodzenie. Zdanie to o tyle nie zasługuje na uwage, że Pismo św. zupełnie jasno wspomina o tym poście praktykowanym przez. Izraelitów jeszcze za życia samej Estery. Było to wyraźnym jej życzeniem, jak również życzeniem Mardocheusza ${ }^{31}$ ).

Jak długo Izraelici zachowywali swe wyżej wspomniane posty, trudno jest na to pytanie odpowiedzieć. Pewnym jest to, że 3 Tiszri z racji śmierci Godaljasza nie poszczono już w II w. przed Chr. Dzień

$\left.{ }^{26}\right)$ Por. Strack-Billerbeck, d. c. t. II, s. 144.

${ }^{27}$ ) Por. Strack-Billerbeck, d. c. t. IV, s. 77.

$\left.{ }^{28}\right)$ for. ks. Kapł. 16, 29; ,i będzie to wam za ustawe wieczną".

${ }^{29}$ ) Por. Est. 9, 29.

${ }^{30}$ ) Por. E. Kalt, Real-Lexikon, Padeborn, 1931.

$\left.{ }^{31}\right)$ Por. Est. 4, 16; 9, 29. 
- ten bowiem od czasów Jana Hyrkana $(135$ - 104) należał do dni w które post ì żałoba były zakazane ${ }^{32}$ ).

Pozostałe trzy posty w miarę odnawiania się życia religijno-społecznego po niowoli zatracały swe znaczenie i ogół Izraelitów ich nie przestı zegał: Możliwem jest, że opierano się na słowach Zachariasza: „Post czwartego i post piątego i post siódmego i post dziesiątego obróci siẹ domowi Judy w wesele i radość znamienite uroczyste święta ${ }^{33}$ ). Post na dzień zburzenia świątyni (9 $\mathrm{Ab}$ ) pozostał jednak mocno w pamięci Izraela i zachowywany był na długie lata. Strack-Billerbeck ${ }^{34}$ ) podaje, że obchodzono go jeszoze po roku 70 po Chr. i obowiązywał jako jedyny narodowy dzień smutku wszystkich Izraelitów.

Ze względu na czas trwania można by podzielić posty Izraelitów na: 1) jednodniowe, rozpoczynajace się wieczorem dniä poprzedniego i kończące się z zachodem słońca dnia następnego. Były to przeważnie surowe i ostre posty.

2) O trzechdniowych postach mamy wzmianke u Tob. 3, 10; Est. 4, 16; II Mach. 13, 12. Charakterystycznym jest tu post, o którym wspomina autor II Mach., ze względu na jego społeczne nastawienie i na cel póstu: wspólna prośba ludu o zwycięstwo nad wrogiem.

3) Post siedmiodniowy, z racji śmierci Saula i jego synów, I. Król. 31, 13.

4) Z, trzechtygodniowym postem spotykamy się u proroka Daniela. Miał on znaczenie prywatne, chociaż celem jego było dobro ogółu. Sam proi ok tak się o tym wyraża: „W owe dni, ja Daniel, płakałem przez dni trzech tygodni, chleba pożadanego nie jadłem, a mięso $i$ wino nie weszło $w$ usta moje, ale ani olejkiem nie namazatem się, az sie wypełniły dni trzech tygodni $\left.{ }^{\text {( } 35}\right)$.

5) Czterdziestodniowy post odprawia Mojżesz na górze Synaj i Eljasz na górze Horeb ${ }^{36}$ ). Pobożni Izraelici, jak podaje E. Kalt ${ }^{37}$ ) na pamiątkę początku i końca tego Mojżeszowego postu, będą później pościć .w każdy poniedziałek i czwartek.

6) „Przez wiele dni“" pościli też Izraelici, ale już całkiem prywatnie i to raczej z większej pobożności. O takim poście wspomina Nehemiasz ${ }^{38}$ )

${ }^{32}$ ) Por. Talmud. Megil. Taanit. 7, cyt, u. Strack-Billerbeck, t. IV, 82.

s3) Por. Zach. 8, 19.

${ }^{34}$ ) Por. Strack-Billerbeck, t. IV, s. 81.

35) Por. Dn. 10, 2.

so) Por. ks. Wyjść. 24, 18; III Król. 19, 8.

57) Por. E. Kalt. Archeologia Bilblijna, Kraków 1937, s. 122.

${ }^{38}$ ) Por. II Ezdr. 1, 4. 
i kapłan Eljakim ${ }^{39}$ ). Ten ostatni czyni to raczej w formie zachęty, aniżeli rozkazu.

7) Post przez całe życie znany jest w Piśmie św. tylko w jednym wypadku. Zdobyła się nań pobożna niewiasta izraelska Judyta ${ }^{40}$ ). Oczywiście z tego postu były wykluczone pierwsze dni miesiąca, soboty, oraz święta domu izraelskiego, ponieważ w te-dni post był zabroniony.

Można by jeszcze ze względu na okoliczności, podzielić posty izraelskie prywatne i publiczne, zwyczajne i nadzwyczajne.

Posty publiczne nadzwyczajne odprawiał cały naród na rozkaz władzy państwowej. Miały one miejsce wtedy, gdy krajowi groziły niebezpieczne wojny połączone z możliwością utraty niepodległości państwowej albo nieszczęścia o charakterze gospodarczo-społecznym.

Jozafat - jak podaje ks. Kronik ${ }^{41}$ ) zarządził publiczny post, gdy Moabici i Amonici najechali na ziemię Judzką. Saul grozi przekleństwem temu, kto by się odważył złamać post, dopóki on nie pomści się nad wrogami Izraela ${ }^{42}$ ). Pięknym jest post całego ludu, zebranego w Masfa obok Jeruzalem przed pokonaniem Nikanora i Gorgiasza pod Emaus ${ }^{43}$ ).

Oryğinalny charakter miał też post, gdy krajowi groziła klęska posuchy, nieurodzaju lủb gdy na ziemię spadły ciężkie plagi. Post wtedy øbowiązywał albo w całym kraju albo tylko w danej okolicy dotkniętej 'tym Iub owym nieszczęściem. Np. gdy na kraj spadła za proroka Joèla szanańcza, od której-pognito bydto, w gnoju swoim obalone sq gumna, spalone spichrze, wtedy P. Bóg przez usta proroka nawoływał specjalnie do postu: ,nawróćcie się do mnie ze wszystkiego serca waszego i pośćcie $w$ płaczu $i$ zalu... Poświẹćcié post $\left.{ }^{44}\right)$. Talmud podaje, że 3 Marcheszwan rozpoczynano w czasie posuehy post na uproszenie deszczu ${ }^{45}$ ). Kiedy mimo postu po dwóch tygodniach deszczu nadal nie było, rozpoczynano post pojedynczo, a gdy i to nie poskutkowało zarządzano post trzydniowy dla wszystkich. Gdyby i to było bezowocne poszczono jeszcze przez 7 dni.

Prywatne posty z reguły nie były nakazywane przez żadną władzę. Wypływały one spontanicznie z pobożnej duszy gorliwego Izraelity

$\left.{ }^{39}\right)$ Por. Jdt. 4, 12.

${ }^{40}$ ) Por. Jud: 8, 6.

41) Por. ks. Kron. 20, 3.

42) Por. I Król. 14, 24.

43) Pór. I Mach. 3, 47.

44) Por. Joel 1, 14, 17; 2, 12; 17.

$\left.{ }^{45}\right)$ Por. Migl. Taanit I, 3-7; cyt. u Strack-Billerbeck, t. IV, s. 83 . 
i były zwykle albo wyrazem pokuty za popełnione winy, albo zawierały w sobie gorąca prośbę o ratunek $\mathrm{z}$ grożącego niebezpieczeństwa. Taki prywatny post odprawiał Dawid, gdy ,prosif za dziecięciem swoim“4" ), Daniel, gdy modlił się za ludem ${ }^{47}$ ), Judyta przez cały okres swojego wdowieństwa. Od II $/$. przed Chr. począwszy posty te przyjęły się już jako stały zwyczaj i były zachowywane, jeśli nie przez cały naród, to przynajmniej przez pewne koła Izraelitów ${ }^{48}$ ).

Dni, w których miały się odbywać posty prywatne, nie były specjalnie wyznaczane. Każdy mógł sobie sam wyznaczyć dzień, który mu najlepiej odpowiadał. Jednak utarł się zwyczaj, że posty te odprawiano w poniedziałki i w czwartki. Zwyczaj ten zakorzenił się tak mocno, że wspomina o nim autor ,Didache“, przeciwstawiając go chrześcijańskim przepisom postu: ,Posty zaś wasze niech nie przypadają razem z obłudnikami (t. j. faryzeuszami). Oni bowiem poszcza w poniedziałki i czwartki, wy natomiast macie pościć w środy i piątki ${ }^{49}$ ). Poza tym wszyscy pragnący pościć prywatnie, musieli się dostosować do ogólnych przepisów, odnośnie do postów ${ }^{50}$ ).

PRZEPIS Y POSTNE. Post Izraelitów opierał się na pewnych przepisach. Dotyczyły one jakości i ilości pokarmów, sposobów ubierania się i zachowania w ezasie postu oraz nabożeństw postnych. Przepisy te zwłaszcza w okresie proroków nie były tak jasno sprecyzowane. Prorocy bowiem kładli większy nacisk na ducha aniżeli na formę postu. Stąd często powtarzający się refren o rozdzieraniu serc a nie szat ${ }^{51}$ ), o umartwianiu swego ,wnętrza“, o szerzeniu zasad sprawiedliwości i mi$\nmid$ łści $^{52}$ ). Z chwilą ustania nauczania proroków, skłonna do formalistyki dusza żydowiska, będzie znowu kładła większy nacisk na formę, aniżeli na treść postu.

Zasadniczy posit, który obowiązywał w dzień pojednania, był bąrdzo ścisłym i surowym postem. Nie przyjmowano w tym dniu żadnych pokarmów ani napojów. Podobnie odprawiano wszystkie inne posty jednodniowe. Jeśli post przeciągał się na więcej dni, przyjmo-

$\left.{ }^{46}\right)$ Por. II Kród, 12, 16.

$\left.{ }^{47}\right)$ Por. Dn. 9, 3.

$\left.{ }^{48}\right)$ Por. Strack-Billerbeck, d. c. t. II, s. 241.

${ }^{49}$ ) Por. „Nauka 12 Apostołów“ w P. O. K., Poznań 1924, t. I, s. 32.

${ }^{50}$ ) Por. O przepisach tych dowiadujemy się z ,Megillat Taanit" — ,zwój postny“, pisma pochodzącego z ok. 70 r. po Chrystusie, napisanego po. aramejsku. Por. Strack-Billerbeck, t. II, s. 242 .

${ }^{51}$ ) Por. Joel. 2, 12.

$\left.{ }^{52}\right)$ Por. Iz. 58, $4 \mathrm{nn}$. 
wano bardzo skromne posiłki, służące tylko podtrzymaniu życia. Ludzie odprawiający post, ubierali się w specjalne szaty, t. zw. wory pokutne i przepasywali powrozem. Wory te były sporządzone $z$ grubego materiału i prawdopodobnie sięgały początkami swoimi czasów t. zw. „płaczków", którzy również w wory pokutne się ubierali, ile razy opłakiwali śmierć zmarłych osób ${ }^{53}$ ). Patriarcha Jakub, kiedy bolał nad stratą Józefa, również ,oblókł się we włosiennicę, płacząc syna swego ${ }^{54}$ ). Włożenie woru pokutnego poprzedzane często było przez rozdzieranie szat, a niekiedy w ogóle przez zdjęcie swoich codziennych szat, a dopiero potem ubranie się w strój pokutny. Równolegle $z$ włożeniem woru pokutnego było siedzenie w popiele i posypywanie nim głowy lub całego ciała. Spotykamy się także z tym, że niekiedy posypywano głowy nie tylko popiołem ale nawet gnojem ${ }^{55}$ ). W czasie postu chodzono zwykle boso, opuszozano mycie i namaszczanie się wonnymi olejkami. Zakaz handlowania i podróżowania w czasie postu jest późniejszego pochodzenia, chociaż wspomina o nim już prorok (Izaj. 58). Również z tego samego okresu pochodza zakazy: odbywania zaręczyn, uroczystości weselnych, jak również udzielania sobie wzajemnego pozdrowienia. Sa to jednak przepisy natury czysto zewnętrznej.

Poza tym w czasie postu odprawiano specjalne nabożeństwa postne, wygłaszano okolicznościowe kazania oraz odbywano uroczyste procesje.

Nabożeństwa miały miejsce albo na rynku jakiegoś miasta, albo na cmentarzu między grobami zmarłych. Zwykle w czasie obrzędów postnych wynoszono skrzynię z Torą na rynek, posypywano ją popiołem, modlono się, leżano w popiele, trąbiono $i$ wygłaszano pobożne nauki. Resztki tych nauk możemy znaleźć dziś jeszcze w rabinistycznej literaturze $\left.{ }^{56}\right)$.

WARTOŚCI WYCHOWAWCZE POSTU. Tak pojęty post miał objąć sobą całego człowieka. Zwracał przede wszystkim uwage na umartwienie. Przepisy o powstrzymaniu się od pokarmów i napojów kryły poza sobą coś więcej: przyzwyczajenie człowieka do ofiary. Specjalnie zwracali na to uwage prorocy, uważając post jako ,'inah naphszo" = umartwienie swojej duszy ${ }^{67}$ ).

$\left.{ }^{53}\right)$ Por. Strack-Billerbeck; d. c. t. IV, s. 103.

${ }^{54}$ ) Por. ks. Rodz. 37, 34.

55) Por. Est. 14, 2.

${ }^{56)}$ W czasie nabożeństwa postnego czytano rano ,Torę", ks. Wyjść. 32, $11 \mathrm{nn}$., a wieczorem Izajasza 55, 6-56, 8.

57) Por. Iz. 58, 3. 
Post miał usźlachetnić człowieka, modlitwy jego uczynić wznioślejsze, oczyścić je ze wszelkich ziemskich naleciałości i zbliżyć do Boga. Dlatego poszczono przed świętami, które najwięcej przypominały człowiekowi tego Boga. Mojżesz pościł, gdy miał z Bogiem rozmawiać ${ }^{58}$ ), Daniel przed otrzymaniem objawienia Bożego, Judyta zaś będzie całe życie pościć, by tylko uczcić Boga.

Pobożni Izraelici byli głęboko przekonani, że post wyprasza ludziom Boże miłosierdzie, dlatego pościli téz w nadziei uproszenia sobie długiego życia i szczęśliwej śmierci. Post u Izraelitów był zatem rzeczą świętą, był nieomal ich chlebem codziennym, był czynnością, która najwspanialej twardą i rogatą duszę żydowską szlifowała i kontaktowała z Bogiem.

Z tego też założenia, wyjdzie kilka wieków później Kościół św., gdy będzie przepisywał swoim wiernym post w Nowym Testamencie. Cel, wartość i znaczenie jego wyjmie ze skarbca Starego Testamentu i zamknie w przepięknej modlitwie do Boga, zawartej po wieczne czasy w prefacji postnej: „Qui corporali jejunio vitia comprimis, mentem elevas, virtutem largiris et proemia".

Kraków. Ks. STANISŁAW GRZYBEK. 